\title{
СИНТЕЗ И ИЗУЧЕНИЕ АНТИКОАГУЛЯЦИОННОЙ И АНТИАГРЕГАЦИОННОЙ АКТИВНОСТИ АМИДОВ МАЛЕОПИМАРОВОЙ И АБИЕТИНОВОЙ КИСЛОТ В УСЛОВИЯХ IN VITRO
}

\section{Н.С. Хуснутдинова', С.А. Мещерякова', А.В. Самородов', Р.М. Султанова ${ }^{2}$}

\author{
${ }^{1}$ Кафедра Общей химии, ФГБОУ ВО БГМУ Минздрава России, \\ 450008, Россия, Республика Башкортостан, г. Уфа, ул. Ленина, д. 3. \\ 2Лаборатория биоорганической химии и катализа, \\ ФГБУН Уфимский Институт химии Российской академии наук, \\ 45054, Россия, г. Уфа, пр. Октября, 71.
}

DOI:10.19163/MedChemRussia2021-2021-451_E-mail: neilyhusnutdinova@yandex.ru

Широко распространенными в растительном мире являются трициклические дитерпеноиды абиетанового ряда, среди которых особый интерес в качестве скаффолдов для конструирования новых лекарственных средств представляют смоляные (дитерпеновые) кислоты [1]. Лидирующие дитерпеновые кислоты абиетиновая и левопимаровая являются легко доступными компонентами смолы сосны Pinus sylvestris L., распространенной на территории России, и используются в качестве основы для получения библиотек биологически активных производных, обладающих различными видами биологической активности [1].

В настоящей работе исследована антикоагуляционная и антиагрегационная активности амидов 6a-d абиетиновой (1) и малеопимаровой (2) кислот, полученных путем ацилирования аминов 5a-d хлорангидридами дитерпеновых кислот 3,4 в присутствии $\mathrm{Et}_{3} \mathrm{~N}$.

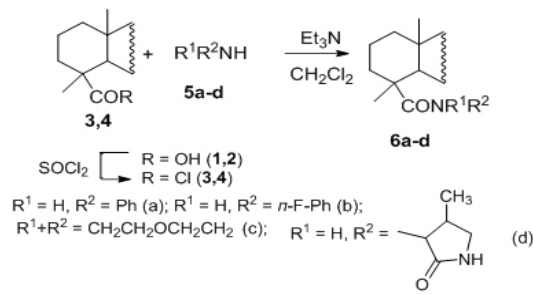

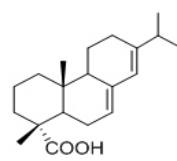

1

абистиновая кислота

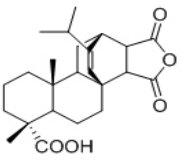

2

малеопимаровая кислота

Согласно полученным результатам, синтезированные амиды дитерпеновых кислот показали различной степени выраженности влияние на плазменный компонент системы гемостаза, проявляющееся изменением показателя внутреннего пути свертывания крови - АПТВ, а также проявили антиагрегационную активность на уровне ацетилсалициловой кислоты, эффективнее подавляя реакцию высвобождения тромбоцитов.

\section{Литература}

[1] Г.А. Толстиков, Т.Г. Толстикова, Э.Э. Шульц, С.Е. Толстиков, М.В. Хвостов, Смоляные кислоты хвойных России, 2011,395 с. 